$c$

$\Sigma$
$\Sigma$
$\Sigma$

(NASA-TY-73691) CBYOGENIC PROPERTIES OF A

NEW IOUGH-STBONG IRON ALLOY (NASA) 13 F HC

A $02 / M F \quad$ L. 01
CSCL 110
N 77-28269

Unclas

39297

CRYOGENIC PROPERTIES OF A NEW

TOUGH-STRONG IRON ALLOY

by Joseph R. Stephens and Walter R. Witzke

Lewis Research Center

Cleveland, Ohio 44135

TECHNICAL PAPER to be presented at the 1977 Internationa Cryogenic Materials Conference conducted by the National Bureau of Standards and the University of Colorado Boulder, Colorado, August 2-5, 1977 


\title{
CRYOGENIC PROPERTIES OF A NEW TOUGH-STRONG IRON ALLOY
}

\author{
by Joseph R. Stephens and Walter R. Witzke \\ National Aeronautics and Space Administration \\ Lew is Research Center \\ Cleveland, Ohio 44135
}

\begin{abstract}
A program was undertaken to develop an iron-base alloy having a fracture toughness of $220 \mathrm{MPa} \cdot \mathrm{m}^{\frac{1}{2}}\left(20 \mathrm{csi} \cdot \mathrm{in}^{\frac{1}{2}}\right)$ with a corresponding yield stress of 1.4 GPa $(200 \mathrm{ksi})$ at $-196^{\circ} \mathrm{C}$. An Fe-12Ni alloy was selected as the base alloy. Factors considered included reactive metal additions, effects of interstitial impurities, sitrengthening mechanisms, and weldability. The goals of this program Wrere met in an Fe-12Ni-0.5Al alloy strengthened by thermomechanical processing or by precipitate strengthening with 2 percent $\mathrm{Cu}$. The alloy is weldable with the weld metal and heat affected zone in the post-weld annealed condition having toughness equivalent to the base alloy.
\end{abstract}

\section{INTRODUCTION}

Nickel-containing steels are frequently selected for use at cryogenic temperatures because of their excellent toughness and/or strengths. For example, 304: stainless steel containing 8 percent nickel is characterized by very high toughness at cryogenic temperatures, but it has relatively low strength. In contrast, $18 \mathrm{Ni}, 200$ grade maraging steel is characterized by very high strengths at cryogenic temperatures, but with a penalty of reduced toughness. Similarly, 9Ni steel is characterized by good toughness and moderate strength at cryogenic temperatures, while 9Ni-4Co steel has greater strength, but substantially lower toughness in the same temperature range.

The purpose of an experimental program conducted at the NASA-Lewis Researcl Center was to identify a single Fe-base alloy that would combine the STAR Category 26 
apparent divergent cryogenic properties of high toughness and high strength. A goal was set for this program to develop an alloy with $-196^{\circ} \mathrm{C}$ properties of fracture toughness equal to $220 \mathrm{MPa} \cdot \mathrm{m}^{\frac{1}{2}}\left(200 \mathrm{ksi} \cdot \mathrm{in}^{\frac{1}{2}}\right)$ and corresponding yield strength equal to $1.4 \mathrm{GPa}(200 \mathrm{ksi})$. The initial work at the University of California, Berkeley Campus, on $\mathrm{Fe}-12 \mathrm{Ni}$ alloys [1] provided an impetus for the direction of our program. One method of achieving high toughness in iron-base alloys for cryogenic service is to keep embritting interstitial element $(C, O$, and $N$ ) concentrations low by alloying with reactive ("gettering") elements which will precipitate them as innocous particles. A total of 11 reactive metals were added to the $\mathrm{Fe}-12 \mathrm{Ni}$ system including $\mathrm{Al}, \mathrm{Hf}, \mathrm{La}$, mischmetal, $\mathrm{Nb}, \mathrm{Si}, \mathrm{Ta}, \mathrm{Ti}$, $\mathrm{V}, \mathrm{Y}$, and $\mathrm{Zr}$. Preliminary studies [2] showed that $\mathrm{Al}, \mathrm{Nb}, \mathrm{Ti}$, and $\mathrm{V}$ were most effective in improving toughness. Aluminum was chosen as the optimum reactive metal for more detailed investigations. Factors considered in the program were optimization of nickel content, optimization of $\mathrm{Al}$ content, the effects of interstitial impurities, strengthening mechanisms, and weldability.

\section{EXPERIMENTAL PROCEDURE}

Alloys were prepared by arc-melting 1 kilogram laboratory size ingots followed by hot rolling to a thickness of 7 millimeters. Rolling was normally at $1100^{\circ} \mathrm{C}$, but temperatures of $650^{\circ}$ and $25^{\circ} \mathrm{C}$ were also employed to investigate the effects of thermomechanical processing on toughness and strength. Aluminum and $\mathrm{Ni}$ optimization were studied in the Fe-Ni-Al alloy system with $\mathrm{Al}$ contents ranging from 0 to 4 atom percent and $\mathrm{Ni}$ contents ranging from 0 to 18 atom percent. Caxbon was intentionally added to the experimental alloys to determine the maximum amount of this impurity that could be tolerated and still maintain high toughness. Carbon was also considered as a possible strengthener along with precipitate strengthening and solid solution strengthening. Weldability of the experimental alloys also was explored using the gas-tungsten arc (GTA) welding technique. Details of the welding techniques can be found elsewhere [3]. Evalua- 
tion of toughness was by slow bend fracture toughness tests on precracked Charpy specimens using the Equivalent Energy $\left(\mathrm{K}_{\mathrm{I}} \mathrm{cd}\right.$ technique [4] to analyze the data. Comparison of results using this technique on Charpy specimens machined from valid $\mathrm{K}_{\mathrm{Ic}}$ specimens has shown good agreement between $\mathrm{K}_{\mathrm{Icd}}$ and valid $\mathrm{I}_{\mathrm{Ic}}$ measurements [5].

\section{RESULTS}

\section{Aluminum Optimization}

Initial efforts were directed at improving the toughness of the $\mathrm{F} \in-12 \mathrm{Ni}$ base alloy as a result of adding reactive metals. The results of these studies [2] indicated that $\mathrm{A} 1$ additions gave the best tradeoff in toughness and strength. The effects of $\mathrm{Al}$ additions on the cryogenic toughness of the $\mathrm{Fe}-12 \mathrm{Ni}$ base alloy are illustrated in figure 1. The three curves shown in this figure represent 2 -hour anneals at temperatures of $550^{\circ} \mathrm{C}$ (single phase $\alpha$ region), $685^{\circ} \mathrm{C}$ (two phase $\alpha+\gamma$ region), and $820^{\circ} \mathrm{C}$ (single phase $\gamma$ region). A maximum in toughness is achieved at an $\mathrm{Al}$ concentration of 0.5 atom percent for the two higher annealing temperatures and from 0.5 to 1.0 atom percent $\mathrm{Al}$ after annealing at $550^{\circ} \mathrm{C}$. The improvement in toughness is attributed to the scavening of interstitial impurities as well as a reduction in grain size by about one-half with these dilute $\mathrm{Al}$ additions to the $\mathrm{Fe}-12 \mathrm{Ni}$ alloy. Because of the sharp drop in toughness for the Fe-12Ni-1.0Al alloy upon annealing at $685^{\circ}$ and $820^{\circ} \mathrm{C}$ (fig. 1), $0.5 \mathrm{Al}$ was selected as the more promising $\mathrm{Al}$ concentration for further detailed studies.

Nickel Optimization

The effects of $\mathrm{Ni}$ content in the Fe-0.5 Al system annealed at $550^{\circ} \mathrm{C}$ and tested at $-196^{\circ} \mathrm{C}$ are shown in figure 2. An improvement in toughness with increasing $\mathrm{Ni}$ content is noted for $\mathrm{Ni}$ contents up to 12 atom percent. Beyond this amount a decrease in toughness occurs at Ni contents to 18 atom percent. Accompanying this drop in toughness is an increase in the amount of retained austenite (as determined by $\mathrm{X}$-ray diffraction) in these alloys. The austenite level is nil in the 
$12 \mathrm{Ni}$ alloy but increases to as high as 18 percent in the $18 \mathrm{Ni}$ alloy. Scanning electron micrographs indicated that fracture at $-196^{\circ} \mathrm{C}$ was primarily by cleavage at $10 \mathrm{Ni}$, a mixture of cleavage and large dimpled fracture at $12 \mathrm{Ni}$, while at $18 \mathrm{Ni}$ the fracture was almost planar and characterized by very fine dimples. The maximum in toughness occurring at the intermediate Ni content of 12 atom percent is believed to be due to the offsetting effects of Ni changing the fracture mode and promoting retained austenite at higher $\mathrm{Ni}$ contents. Toughness increased as the fracture mode changed from cleavage (which normally is characteristic of brittie, low toughness materials) at 8 to $10 \mathrm{Ni}$ to primarily dimpled clupture at a $12 \mathrm{Ni}$ content and above. Beyond $12 \mathrm{Ni}$ the presence of retained austenite lowered the yield strength which in turn reduced the toughness as austenite content further increased.

\section{Effects of Welding}

The weldability of the Fe-12Ni-0.5Al alloy is illustrated in figure 3, where the ratio of tougluness for either weld metal ox the heat affected zone (HAZ) to that of the base alloy are compared for the alloy in different conditions. The weld conditions shown are as hot-rolled, annealed at $550^{\circ} \mathrm{C}$ prior to welding, and hotrolled, welded plus a post-weld heat treatment at $550^{\circ} \mathrm{C}$. It should bo noted that for the $\mathrm{Fe}-12 \mathrm{Ni}-0.5 \mathrm{Al}$ alloy a post-weld heat treatment is required to achieve toughness in the weld or $\mathrm{HAZ}$ comparable to that in the base metal.

The weldability of the Fe-12Ni base alloy containing two other reactive metal additions is also shown in figure 3. An Fe-12Ni-0.25Ti exhibits excellent toughness in the weld or HAZ tunder all test conditions. In contrast, an Fe-12Ni-0.25Nb alloy exhibits poor weldability under all test conditions. Electron microprobe scans showed that $\mathrm{Nb}$ segregation to dendritic cell boundaries in the weld and $\mathrm{HAZ}$ probably accounts for the poor welclability in the Fe-12Ni-0.25Nb alloy. From these results, Ti additions sre considered to be most effective in providing good weldability in the $\mathrm{Fe}-12 \mathrm{Ni}$ alloy, while $\mathrm{Al}$ additions also produce excellent weldabillit the alloy is given a post-weld anneal. 
The results described above have shown that an Fe-12Ni-0.5Al alloy possesses cryogenic toughness in excess of the $220 \mathrm{MPa} \cdot \mathrm{m}^{\frac{1}{2}}$ goal set for this program. The yield strength of this alloy typically ranged from 0.9 to $1.1 \mathrm{GPa}$, or about 65 to 70 percent of the $1.4 \mathrm{GPa}$ strength goal.

\section{Effects of Carbon Addlitions}

Research efforts were subsequently directly at strengthening the Fe-12Ni-0.5Al alloy. Solid solution strengtheising was abandoned early in the investigation because this approach caused the ductile-brittle transition temperature to increase with a corresponding drop In toughness.

Figure 4: shows the effects of carbon additions on this alloy where strength and toughness are compared for alloys annealed in olther the $\alpha$ or $\alpha+\gamma$ regions, $550^{\circ}$ and $685^{\circ} \mathrm{C}$, respectively. For both conditions, yield strength increases rapidly with small $\mathrm{C}$ additions (up to slightly less than $100 \mathrm{ppm} \mathrm{C}$, by weight. Above this concentration there was a continual slight increase in strength with increasing $\mathrm{C}$ content up to the maximum level studied $(1800 \mathrm{ppm} \mathrm{C)}$. At $550^{\circ} \mathrm{C}$, the solutibility of $\mathrm{C}$ in $\alpha \mathrm{Fe}$ is about $60 \mathrm{ppm} \mathrm{C}$, approximately the level where rapid strengthening ceases in this alloy. Maximum toughness is achieved in this alloy ai a carbon content of about $60 \mathrm{ppm}$, but the toughness goal of $220 \mathrm{MPa} \cdot \mathrm{ml}^{\frac{1}{2}}$ can be met over a carbon range from 40 to about $600 \mathrm{ppm}$. The strength goal of 1.4 GPa was only achieved in this alloy at tho maximum studied $\mathrm{C}$ content of $1800 \mathrm{ppm}$ for the $685^{\circ} \mathrm{C}$ annealed material. However, at this $\mathrm{C}$ content, toughness dropped off to $60 \mathrm{MPa} \cdot \mathrm{m}^{\frac{1}{2}}$. Based on the rapid drop in toughness beyond 100 to $200 \mathrm{ppm} \mathrm{C}$ and the reduced strengthening rate with increasing $\mathrm{C}$ content beyond this concentration, an Fe-12Ni-0.5 Al with about $150 \mathrm{ppm} \mathrm{C}$ is considered to be the optimum composition in this alloy series. Toughness exceeds the $220 \mathrm{MPa} \cdot \mathrm{m}^{\frac{1}{2}}$ goal and a yield strength of $1.1 \mathrm{GPa}$ can be achieved for the $685^{\circ} \mathrm{C}$ anneal. 
Effects of Thermomechanical Processing.

In addition to the standard $1100^{\circ} \mathrm{C}$, hot-rolling procedure, ingots were rolled at $650^{\circ} \mathrm{C}$ (within the $\alpha+\gamma$ region) and at room temperature to evaluate thermomechanical processing effects on the strength of Fe-12Ni-0.5Al. Results showed that the $650^{\circ} \mathrm{C}$ rolled material was slightly stronger than the $1100^{\circ} \mathrm{C}$ hot-rolled material. The effects of the $1100^{\circ}$ and $25^{\circ} \mathrm{C}$ thermomechanical treatments on cryogenic strength and toughness of $\mathrm{Fe}-12 \mathrm{Ni}-0.5 \mathrm{Al}$ are shown in figure 5 as a function of annealing temperature. Annealing the rolled materials within the temperature range of about $550^{\circ}$ to $625^{\circ} \mathrm{C}$ rest-:ed in maximum cryogenic toughness (i. e., $-196^{\circ} \mathrm{C}$ toughness in excess of $220 \mathrm{MPa} \cdot \mathrm{m}^{\frac{1}{2}}$ ). Above about $625^{\circ} \mathrm{C}$ toughness for both rolled conditions decreased rapidly with increasing annealing temperature. In contrast, the cryogenic strength of $1100^{\circ} \mathrm{C}$ rolled materials was near $0.97 \mathrm{GPa}$ over the annealing temperature range of $500^{\circ}$ to $625^{\circ} \mathrm{C}$ and then increased to about $1.1 \mathrm{GPa}$ at annealing temperatures of $650^{\circ}$ to $820^{\circ} \mathrm{C}$. The strength of cold rolled material was, in general, independent of annealing temperature over the range $500^{\circ}$ to $820^{\circ} \mathrm{C}$ and was very near the strength goal of $1.4 \mathrm{GPa}$. Thus, the $-196^{\circ} \mathrm{C}$ toughness and strength goals can both be met in cold worked $\mathrm{Fe}-12 \mathrm{Ni}-0.5 \mathrm{Al}$ annealed over the temperature range $550^{\circ}$ to $625^{\circ} \mathrm{C}$.

\section{Effects of Copper Additions}

A final method of strengthening Fe-12Ni-0.5Al involved precipitate strengthening, copper was chosen as the precipitate material since it has very low solubility in $\mathrm{Fe}$ and precipitates as a copper-rich terminal solid solution containing a small amount of iron. Copper thus would not be expected to form an embrittling intermetallic compound. Copper additions ranging from 0.5 to 3.0 atom percent were investigated, with optimum strength and toughness being achieved at 2 percent $\mathrm{Cu}$. Further results showed that annealing at $450^{\circ} \mathrm{C}$ gave the highest strength while still maintaining the toughness goal. 
Strengthening in the $\mathrm{Fe}-12 \mathrm{Ni}$ system due to $\mathrm{Cu}$ is illustrated in figure 6 . This figure summarizes the beneficial effects of both $\mathrm{Al}$ and $\mathrm{Cu}$ to the $\mathrm{Fe}-12 \mathrm{Ni}$ base allivy. Copper increases the strength of Fe-12Ni with little improvement in toughness, while aluminum dramatically increases toughness with an accompanying increase in strength. These two effects are synergistic, as shown for the Fe-12Ni-0.5Al-2 Cu alloy. The $-196^{\circ} \mathrm{C}$ strength of this alloy is $1.6 \mathrm{GPa}$ with a corresponding toughness of $220 \mathrm{MPa} \cdot \mathrm{m}^{\frac{1}{2}}$. Copper is believed to be effective bem cause of two possible mechanisms. First is the presence of very fine Cu precipitate particles, less than $400 \mathrm{~A}$ in diameter, as shown by the transmittion electron micrograph in figure 7. Dislocations are noted to bow around these particles, contributing primarily to strengthening in these alloys. Secondly, as Cu content was increased from 0.5 to 2 atom percent in the Fe-12Ni-0.5Al alloy, the martensite lath width decreased from 0.65 to 0.27 micrometer as slown for the $2 \mathrm{Cu}$ addition in figure 7 . This decrease in lath width further contributes to strength.

\section{DISCUSSION}

The results of this study have shown that it is possible to combine both high toughness and high strength in air $\mathrm{Fe}-12 \mathrm{Ni}-0.5 \mathrm{Al}$ alloy at $-196^{\circ} \mathrm{C}$. These results were achieved by optimizing the $\mathrm{Ni}$ and $\mathrm{Al}$ contents to achieve high fracture toughness, which reached a maximum value of about $310 \mathrm{MPa} \cdot \mathrm{m}^{\frac{1}{2}}$. This high toughness was developed in an alloy containing about $100 \mathrm{ppm} \mathrm{C}$ that was aged at $550^{\circ} \mathrm{C}$ to produce a microstructure consisting primarily of martensite and ferrite. High toughness is achieved by maintaining this microstructure with the absence of any austenite, which is inherrently weaker than the body centered cubic phases and in turn lowers the toughness as was demonstrated for higher Ni content alloys containing retained austenite. Results also have shown that toughness was greatly reduced in alloys containing oxygen as the predominant interstitial impurity. The primary role of the reactive metal $\mathrm{Al}$ is to scavenge such impurities to render them innecuous in the alloy. Grain size also decreased with Al additions, further 
increasing strength and toughness. The Fe-12Ni-0.5 Al can be welded by the GTA process and, after post-weld heat treatment, has toughness in the weld metal and HAZ comparable to that of the base metal. Strengthening in this alloy system was achieved by three methods, including the intentional addition of carbon, thermomechanical processing, and precipitated $\mathrm{Cu}$.

A comparison of this series of experimental alloys with several commercial steels for cryogenic service is shown in figure 8. Toughness decreases with increase in strength for both the experimental alloy and the commercial steels. At a strength level near, that for 200-grade maraging steel, the Cu-strengthened alloy has over a two-fold advantage in toughness. Further, at the toughness level for 304 stainless steel, the experimental slloys offer over a two-fold advantage in strength.

\section{CONCLUSIONS}

Based on a study of toughness and strength of $\mathrm{Fe}-\mathrm{Ni}-\mathrm{Al}$ alloys for cryogenic service, the following conclusions are drawn:

1. An optimum Ni content of 12 atom percent and an optimum $\mathrm{Al}$ content of 0.5 atom percent provide an alloy with exceptionally high toughness and moderate strength at $-196^{\circ} \mathrm{C}$.

2. The $\mathrm{Fe}-12 \mathrm{Ni}-0.5 \mathrm{Al}$ alloy can be further strengthened with $\mathrm{Cu}-\mathrm{rich}$ precipitates to meet the 1. $4 \mathrm{GPa}(200 \mathrm{ksi})$ yield strength goal of this program and still maintain the toughness goal of $220 \mathrm{MPa} \cdot \mathrm{m}^{\frac{1}{2}}\left(200 \mathrm{ksi} \cdot \mathrm{in}^{\frac{1}{2}}\right)$.

3. Thermomechanical processing and the addition of about $150 \mathrm{ppm}$ carbon are additional effective methods of strengthening while maintaining high toughness.

4. Post-weld annealing of welded material produces toughness in the weld and heat affected zones compr rable to that of the base alloy.

\section{RETERENCES}

1. S. Jin, J. W. Morris, Jx., and V. F. Zackey in: Advances in Cryogenic Engineering, Vol. 19 (15. D. Timmerbaus, editor): Plenum Press, New York (1974), p. 379 . 
2. W. R. Witzke and J. R. Stephens, NASA TN D-8232 (1976),

3. J. H. Devletian, J. R. Stephens, and W. R. Witzke, Welding J., Res. Suppl., 56(4): 97-s (1977).

4. F. J. Witt and T, R. Mayer, ORNL-TM-3894 (1972).

5. W. R. Witzke and J. R. Stephens, submitted for publication in Journal of Testing and Evaluation. 


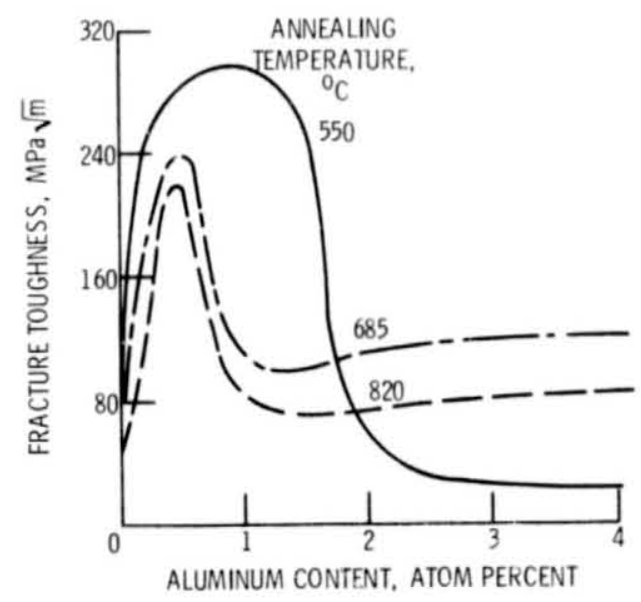

Figure 1. - Effect of aluminum content on fracture toughness of $\mathrm{Fe}-12 \mathrm{Ni}-\mathrm{Al}$ alloys at $-196^{\circ} \mathrm{C}$.

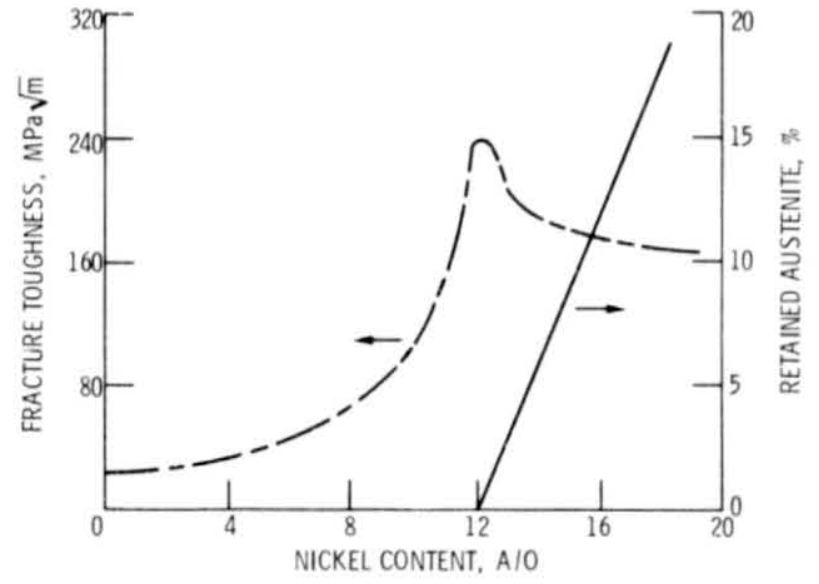

Figure 2. - Effect of nickel content on fracture toughness and retained austenite of $\mathrm{Fe}-\mathrm{Ni}-0.5 \mathrm{Al}$ alloys annealed at $550^{\circ} \mathrm{C}$ and iested at $-196^{\circ} \mathrm{C}$.

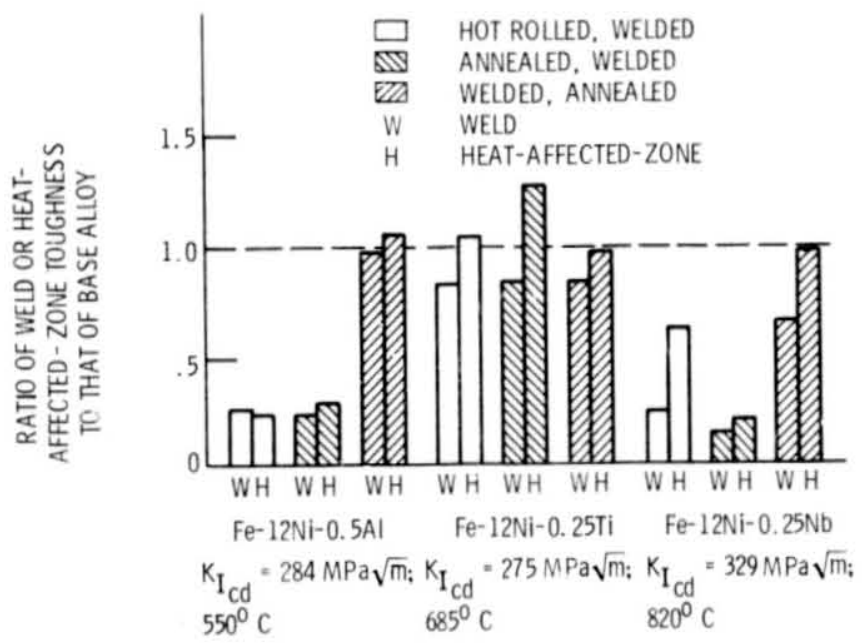

Figure 3. - Effects of pre- and postweld heat treatments on $-196^{\circ} \mathrm{C}$ fracture toughness of welded $\mathrm{Fe}-12 \mathrm{Ni}$ alloys compared to base alloy heat treated for maximum toughness. 


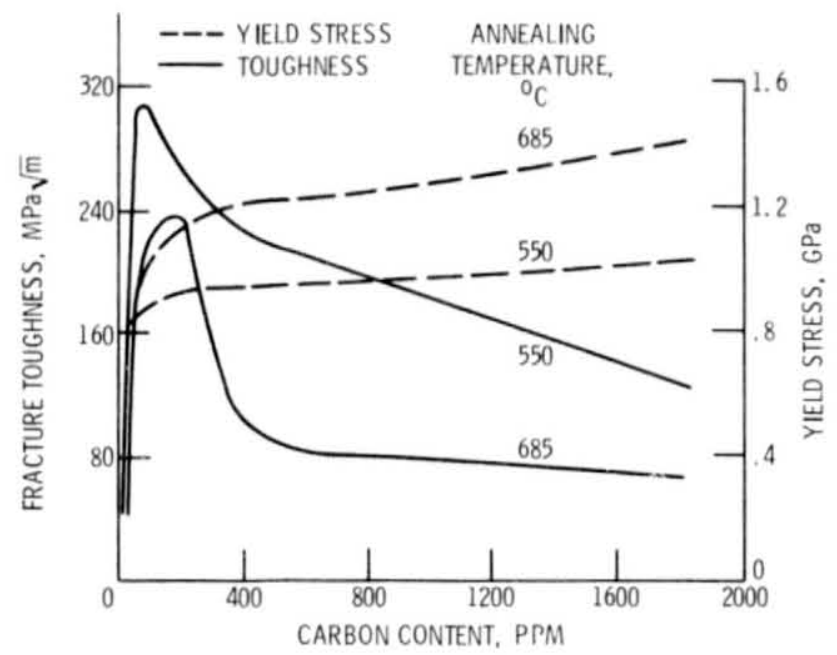

Figure 4. - Effect of carbon content on fracture toughness and yield stress of Fe-12Ni-0.5Al alloy at $-196^{\circ} \mathrm{C}$.

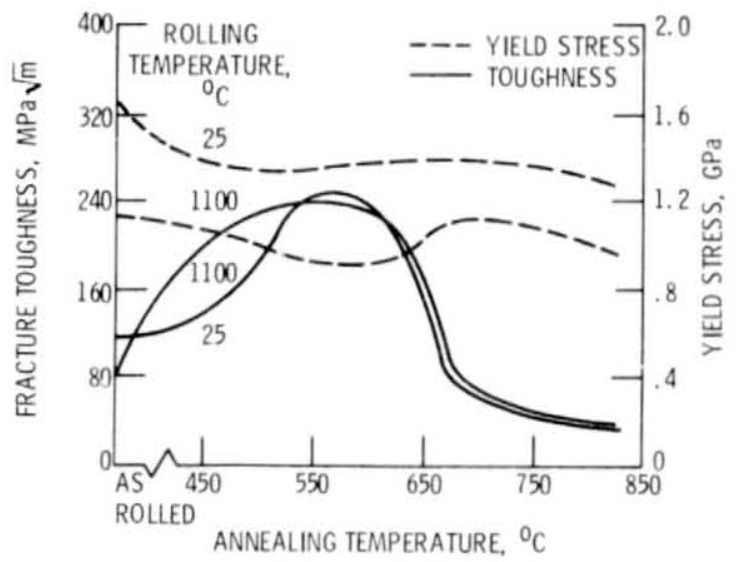

Figure 5. - Effects of thermomechanical processing on fracture toughness and yield stress of $\mathrm{Fe}-12 \mathrm{Ni}-0.5 \mathrm{Al}$ alloy at $-196^{\circ} \mathrm{C}$.

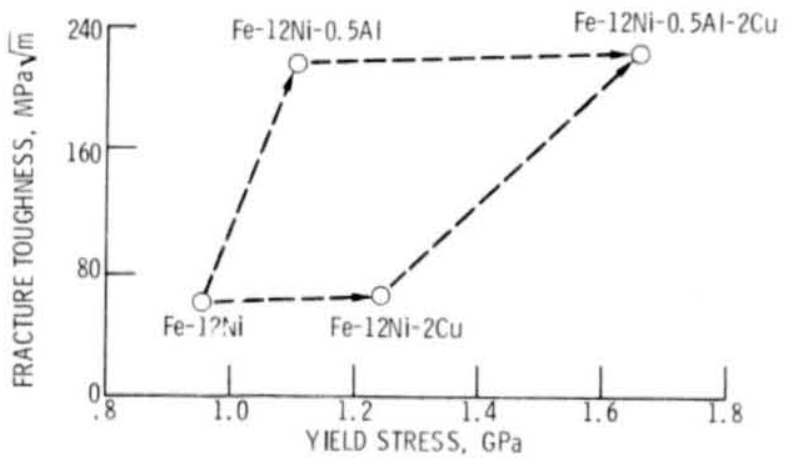

Figure 6. - Contributions of $\mathrm{Al}$ and $\mathrm{Cu}$ to toughness and strength of $\mathrm{Fe}-12 \mathrm{Ni}$ alioy annealed at $450^{\circ} \mathrm{C}$ and tested at $-196^{\circ} \mathrm{C}$. 


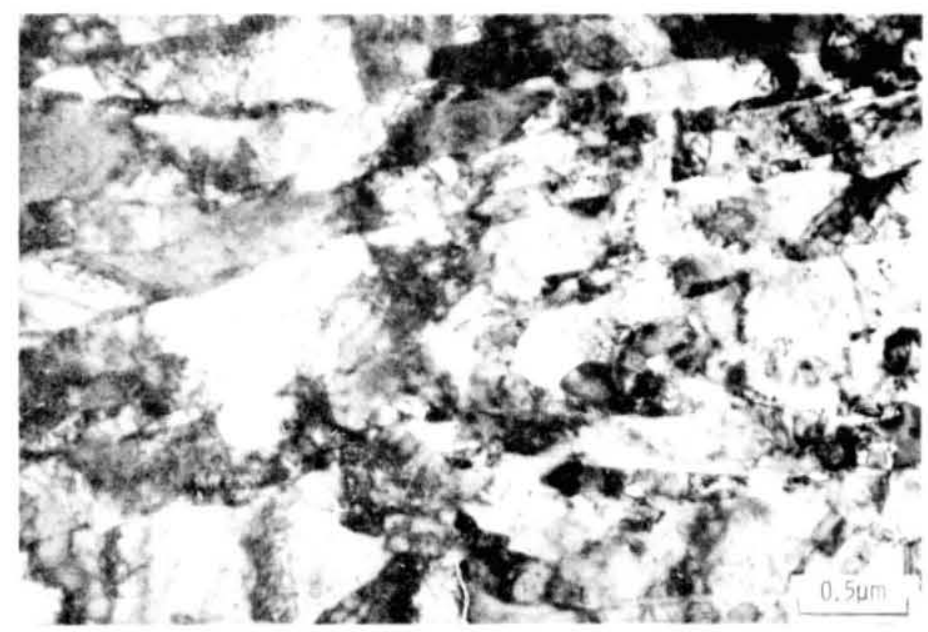

Fiqure 7. - Transmission electron micrograph of $\mathrm{Fe}-1 \mathrm{NNi}-0.5 \mathrm{Al}-2 \mathrm{Cu}$ alloy illustrating bowing of dislocation around less than $400 \mathrm{~A}$ diameter $\mathrm{Cu}$ precipitates.

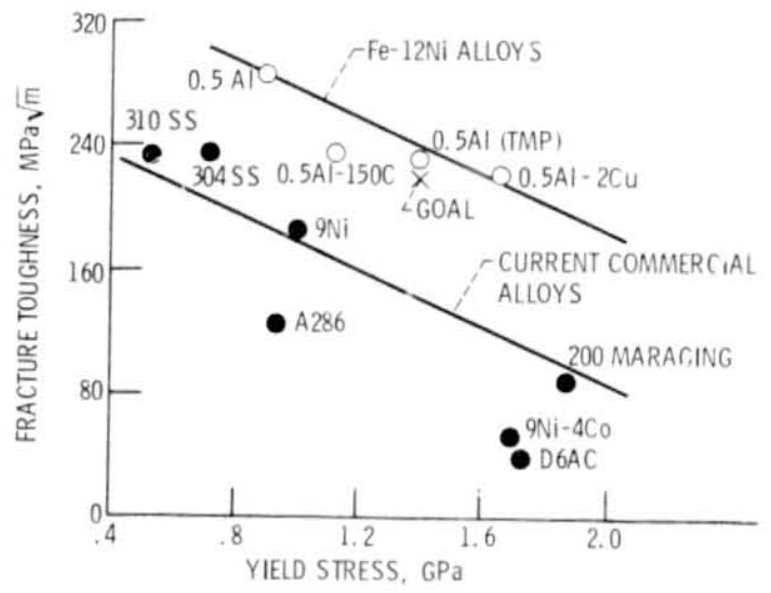

Figure 8. - Comparison of fracture toughness and yield stress of $\mathrm{Fe}-12 \mathrm{Ni}$ experimental alloys with commercial steels at $-196^{\circ} \mathrm{C}$. 